\title{
Nanofiltration for water and wastewater treatment - a mini review
}

\author{
H. K. Shon ${ }^{1}$, S. Phuntsho ${ }^{1}$, D. S. Chaudhary ${ }^{1}$, S. Vigneswaran ${ }^{1}$, and J. Cho ${ }^{2}$ \\ ${ }^{1}$ School of Civil and Environmental Engineering, University of Technology, Sydney (UTS), \\ P.O. Box 129, Broadway, NSW 2007, Australia \\ ${ }^{2}$ Department of Civil and Environmental Engineering, Yonsei University, Yonsei-ro 50, \\ Seodaemun-gu, Seoul 120-749, Korea
}

Correspondence to: H. K. Shon (hokyong.shon-1@uts.edu.au)

Received: 19 February 2013 - Published in Drink. Water Eng. Sci. Discuss.: 13 March 2013

Revised: 26 April 2013 - Accepted: 8 May 2013 - Published: 5 June 2013

\begin{abstract}
The application of membrane technology in water and wastewater treatment is increasing due to stringent water quality standards. Nanofiltration (NF) is one of the widely used membrane processes for water and wastewater treatment in addition to other applications such as desalination. NF has replaced reverse osmosis (RO) membranes in many applications due to lower energy consumption and higher flux rates. This paper briefly reviews the application of NF for water and wastewater treatment including fundamentals, mechanisms, fouling challenges and their controls.
\end{abstract}

\section{Introduction}

Membrane filtration is a pressure driven process in which membrane acts as selective barriers to restrict the passage of pollutants such as organics, nutrients, turbidity, microorganisms, inorganic metal ions and other oxygen depleting pollutants, and allows relatively clear water to pass through (Mulder, 1997). With technological advances and the everincreasing stringency of water quality criteria, membrane processes are becoming a more attractive solution to the challenge of quality water, and water reuse (Shannon et al., 2008). Several studies have been done on the application of microfiltration/ultrafiltration for wastewater treatment and reuse (Vigneswaran et al., 1991; Seo et al., 1996, 1997; Snoeyink et al., 2000; Visvanathan et al., 2000; Ben Aim and Semmens, 2001; Kim et al., 2001; Matsui et al., 2001a, b).

The membrane process has been classified into four broad categories as depending on their pore sizes as: microfiltration (MF), ultrafiltration (UF), nanofiltration (NF) and reverse osmosis (RO) membranes. This paper briefly reviews the application of NF for water and wastewater treatment including for water reuse. This article begins with the brief fundamentals of membrane process followed by discussion on the mechanisms of NF process and its few basic models.
The article also covers the challenges of NF fouling and their control mechanisms adopted to mitigate fouling. Finally the article concludes with a brief summary.

\section{Fundamentals of membrane process}

There are many types of membrane processes in use. RO membrane is essentially non-porous, and it preferentially passes liquid and retains most of the solutes including ions. The RO is characterized by high operating pressure (20 to $100 \mathrm{bar}$ ). NF has pore size $1-5 \mathrm{~nm}$ and it can retains ions, and low molecular weight organics. It has significantly higher water permeability than that of RO membrane and operates at lower pressure (typically 7 to 30 bar). Similarly, UF membrane has pore size typically 5 to $20 \mathrm{~nm}$ and retains fine colloids, macromolecules, and microorganism. The UF operates with pressure range of 1 to $10 \mathrm{bar}$. The other membrane processes that are used in liquid separation process are microfiltration (MF), electrodialysis (ED), liquid membrane (LM), pervaporation $(\mathrm{PV})$, vapour permeation (VP), and gas permeation (GP). The types of membrane processes, the particle size typically removed by the membrane, and the driving force of the processes are illustrated in Fig. 1. The major 


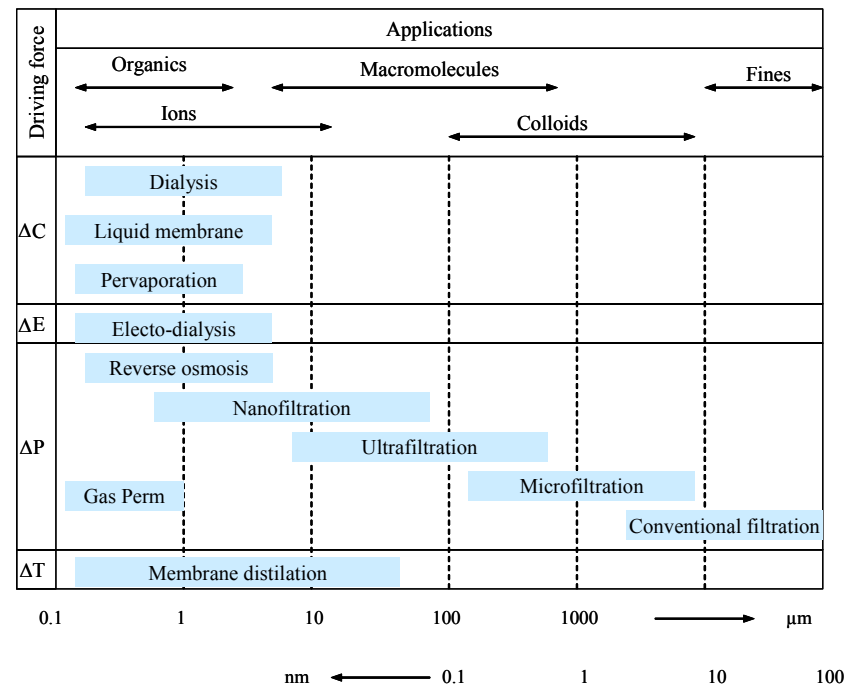

Figure 1. Effective range of membrane processes.

difference between these membrane processes is shown in Table 1.

\section{Nanofiltration}

$\mathrm{NF}$ is the most recently developed pressure-driven membrane process for liquid-phase separations. NF has replaced reverse osmosis (RO) in many applications due to lower energy consumption and higher flux rates (Cadotte et al., 1988; Gozalvez et al., 2002). The properties of NF membranes lie between those of non-porous RO membranes (where transport is governed by a solution-diffusion mechanism) and porous ultrafiltration (UF) membranes (where separation is usually assumed to be due to size exclusion and, in some cases, charge effects). Commercial NF membranes possess a fixed charge developed by dissociation of surface groups such as sulphonated or carboxyl acids. The properties of NF membranes, therefore, allow ions to be separated by a combination of the size and electrical effects of UF and the ion interaction mechanisms of RO (Bowen and Welfoot, 2002).

The NF membrane is the relatively newly introduced technology in wastewater treatment system. The size of pores in NF membranes (nominally $\sim 1 \mathrm{~nm}$ ) is such that even small uncharged solutes are highly rejected while the surface electrostatic properties allow monovalent ions to be reasonably well transmitted with multivalent ions mostly retained. These characteristics make NF membranes extremely useful in the fractionation and selective removal of solutes from complex process streams. The development of NF technology as a viable process over recent years has led to a remarkable increase in its application in a number of industries such as treatment of pulp-bleaching effluents from the textile industry, separation of pharmaceuticals from fermentation broths, demineralization in the dairy industry, and metal recovery from wastewater and virus removal (Bowen et al., 2002).

$\mathrm{NF}$ is one of the promising technologies for the treatment of natural organic matter and inorganic pollutants in surface water. Since the surface water has low osmotic pressure, a low-pressure operation of NF is possible. There is a high rejection of organic substances such as disinfection-byproducts precursors by the NF process. In the NF of surface waters, natural organic compounds, which have relatively large molecules compared to membrane pore size, could be removed by sieving mechanism, whereas the inorganic salts by the charge effect of the membranes and ions (Thanuttamavong et al., 2001, 2002). The past studies on NF are summarized in Table 2 (Ernst et al., 2000; Xu and Lebrun, 1999; Tsuru et al., 2000; Seidel and Elimelech, 2002; Van der Bruggen et al., 2002; Lee et al., 2002; Choi et al., 2002; Trebouet et al., 2001).

\section{Separation mechanisms in NF}

Since NF membrane exhibits properties between those of ultrafiltration (UF) and reverse osmosis (RO), both charge and size of particle play important role in NF rejection mechanism. Simpson et al. (1987) has described NF as a charged UF system whereas Rohe et al. (1990) has referred it as low pressure RO system. However, NF has advantages of lower operating pressure compared to $\mathrm{RO}$, and higher organic rejection compared to UF. For the colloids and large molecules, physical sieving would be the dominant rejection mechanism whereas for the ions and lower molecular weight substances, solution diffusion mechanism and charge effect of membrane play the major role in separation process. Macoun (1998) presented the NF rejection mechanisms into following five steps.

- Wetted surface - water associates with the membrane through hydrogen bonding and the molecules which form the hydrogen bonding with the membrane can be transported.

- Preferential sorption/Capillary rejection - membrane is heterogeneous and microporous, and electrostatic repulsion occurs due to different electrostatic constants of solution and membrane.

- Solution diffusion - membrane is homogeneous and non-porous, and solute and solvent dissolve in the active layer of the membrane and the transport of the solvent occurs due to the diffusion through the layer.

- Charged capillary - electric double layer in the pores determines rejection. Ions of same charge as that of membrane are attracted and counter-ions are rejected due to the streaming potential. 
Table 1. Difference between MF, UF, NF, and RO.

\begin{tabular}{lllll}
\hline Particular & MF & UF & NF & RO \\
\hline Membrane & Porous isotropic & Porous asymmetric & $\begin{array}{l}\text { Finely porous } \\
\text { asymmetric/composite }\end{array}$ & $\begin{array}{l}\text { Nonporous } \\
\text { asymmetric/composite }\end{array}$ \\
\hline Pore size & $50 \mathrm{~nm}-1 \mu \mathrm{m}$ & $5-20 \mathrm{~nm}$ & $1-5 \mathrm{~nm}$ & - \\
\hline $\begin{array}{l}\text { Transfer } \\
\text { mechanism }\end{array}$ & $\begin{array}{l}\text { Sieving and adsorptive } \\
\text { mechanisms (the solutes } \\
\text { migrate by convection) }\end{array}$ & $\begin{array}{l}\text { Sieving and preferential } \\
\text { adsorption }\end{array}$ & $\begin{array}{l}\text { Sieving/electrostatic } \\
\text { hydration/diffusive }\end{array}$ & $\begin{array}{l}\text { Diffusive (solutes migrate } \\
\text { by diffusion mechanism) }\end{array}$ \\
\hline $\begin{array}{l}\text { Law governing } \\
\text { transfer }\end{array}$ & Darcy's law & Darcy's law & Fick's law & Fick's law \\
\hline $\begin{array}{l}\text { Typical solution } \\
\text { treatment }\end{array}$ & $\begin{array}{l}\text { Solution with solid } \\
\text { particles }\end{array}$ & $\begin{array}{l}\text { Solution with colloids } \\
\text { and/or macromolecules }\end{array}$ & Ions, small molecules & Ions, small molecules \\
\hline $\begin{array}{l}\text { Typical pure water } \\
\text { flux }\left(\mathrm{L} \mathrm{m}^{-2} \mathrm{~h}\right)\end{array}$ & $500-10000$ & $100-2000$ & $20-200$ & 10-100 \\
\hline $\begin{array}{l}\text { Pressure } \\
\text { requirement } \\
\text { (atoms) }\end{array}$ & $0.5-5$ & $1-10$ & $7-30$ & $20-100$ \\
\hline
\end{tabular}

Table 2. Past studies of nanofiltration.

\begin{tabular}{|c|c|c|}
\hline Membrane & Pretreatment/Feed solution & Remarks \\
\hline $\begin{array}{l}\text { - Four types of flat sheet membranes: DK5 } \\
\text { (polysulfone }+ \text { polypiperazinamide), PES } 10 \\
\text { (polyethersulfone), C5F (cellulose), and MP } 36 \\
\text { (modified PVDFK) with MWCO 200, } 1000 \text {, } \\
\text { 5000, and 1000, respectively }\end{array}$ & $\begin{array}{l}\text { PAC adsorption, Tertiary wastewater efflu- } \\
\text { ent for ground water recharge }\end{array}$ & $\begin{array}{l}\text { Cut-off characteristics of membrane play impor- } \\
\text { tant role to remove smaller molecular weight } \\
\text { substances }\end{array}$ \\
\hline $\begin{array}{l}\text { - Two types of flat sheet membranes: NF70 } \\
\text { (negatively charged), NF45 (hydrophilic, pore } \\
\text { size } 2-5 \mathrm{~nm} \text { ) }\end{array}$ & $\begin{array}{l}\text { No pretreatment, Electrolytic solutions } \\
\left(\mathrm{NaCl}, \mathrm{Na}_{2} \mathrm{SO}_{4} \text {, and polyethylene glycol) }\right.\end{array}$ & $\begin{array}{l}\text { The transport of solute through NF depends on } \\
\text { sieving mechanism and surface force interaction. }\end{array}$ \\
\hline $\begin{array}{l}\text { - Three inorganic stirred cell membranes with } \\
\text { MCO 200, 600, and } 2000 \text {. }\end{array}$ & $\begin{array}{l}\text { No pretreatment, different electrolytic } \\
\text { solutions }\end{array}$ & $\begin{array}{l}\text { The rejection of solutes decreased but the perme- } \\
\text { ate volume increased with an increase in temper- } \\
\text { ature. }\end{array}$ \\
\hline - Thin film composite, flat sheet membranes & No pretreatment, NOM solutions & $\begin{array}{l}\text { NOM fouling of NF membranes is governed by } \\
\text { the combined effects of initial permeate flux or } \\
\text { applied pressure, crossflow velocity and divalent } \\
\text { (calcium) ion concentration. }\end{array}$ \\
\hline - Flat sheet membrane NF70 & No pretreatment, 14 chemical solutions & $\begin{array}{l}\text { Flux decline is caused by the molecules that fill } \\
\text { the pores of the membrane and adsorption of } \\
\text { molecules on the membrane surfaces which is } \\
\text { enhanced by the hydrophobicity of the solutes. }\end{array}$ \\
\hline $\begin{array}{l}\text { - Polyamide TFC flat sheet membrane with } \\
\text { MWCO } 250 \text { Dalton }\end{array}$ & No pretreatment, different NOM solutions & $\begin{array}{l}\text { Mass transport is more affected by difference in } \\
\text { NOM structure than solution chemistry, and is } \\
\text { dominated by diffusion. }\end{array}$ \\
\hline $\begin{array}{l}\text { - Cellulose acetate hollow fibre submerged } \\
\text { membrane, aerated. }\end{array}$ & No pretreatment, synthetic wastewater & $\begin{array}{l}\text { Low pressure NF bioreactor can be used for long- } \\
\text { term without fatal fouling and cleaning. }\end{array}$ \\
\hline $\begin{array}{l}\text { - MPT- } 20 \text { and MPT- } 31 \text { made of polyster } \\
\text { with polyacrilonitrile support and polypropy- } \\
\text { lene with polysulphone support, respectively, } \\
\text { MWC } 450 \mathrm{Da} \text { and negatively charged }\end{array}$ & $\begin{array}{l}\text { Ferric chloride coagulation - filtration } \\
(10 \mu \mathrm{m} \text { polypropylene mesh), Landfill } \\
\text { leachate }\end{array}$ & $\begin{array}{l}\text { Presence of } \mathrm{Fe}^{3+} \text { ions may change the surface } \\
\text { charges, ionic force of solutions and the struc- } \\
\text { ture of membrane surface, and thus may reduce } \\
\text { the organic retention capacity of the membrane }\end{array}$ \\
\hline $\begin{array}{l}\text { - Polyamide, negatively charged, } 200 \mathrm{Da} \\
\text { MWCO }\end{array}$ & $\begin{array}{l}\text { Millipore filtered }(10 \mu \mathrm{m} \text { and } 1 \mu \mathrm{m}) \text { feed, } \\
\text { Secondary sewage effluent }\end{array}$ & $\begin{array}{l}\text { Fouling due to colloids (such polysaccharides } \\
\text { or proteins) are more severe than the hybropho- } \\
\text { bic and transphilic fractions of organics in the } \\
\text { sewage effluent. }\end{array}$ \\
\hline
\end{tabular}


- Finely porous - membrane is a dense material punctured by pores. Transport is determined by partitioning between bulk and pore fluid.

The characteristics of NF membranes lies between the non-pores reverse osmosis membranes (where the rejection is due to solution-diffusion mechanism) and porous UF membranes (where the rejection is by size exclusion and electrostatic charge effects). Thus, the rejection of uncharged molecules is dominated by size exclusion, while that of ionic species is influenced by both size exclusion and electrostatic interactions. Electrostatic characteristics of NF membranes have been known as playing an important role in rejection anions, namely, negative zeta potential on the membrane surface varies with different $\mathrm{pH}$ and concentration of an electrolyte solution (Choi et al., 2002) .

\section{Mathematical modelling of nanofiltration process}

NF is a complex phenomenon. The NF membranes exhibit properties between those of RO membranes and UF membranes, and hence the solution-diffusion mechanism, the size exclusion, and charge effects need to be considered in modeling the governing phenomenon of NF process. The basic equation to describe the transport of ions/solutes through the membranes is given by the extended Nernst-Planck equation (Eq. 1).

$$
J=D_{p} \frac{\mathrm{d} c}{\mathrm{~d} x}-\frac{z c D_{p}}{R T} F \frac{\mathrm{d} \psi}{\mathrm{d} x}+K_{c} c V
$$

where, $J=$ Ion flux based on membrane area $\left(\mathrm{mol} \mathrm{m}^{-2} \mathrm{~s}^{-1}\right)$, $D_{p}=$ Hindered diffusivity $\left(\mathrm{m}^{2} \mathrm{~s}^{-1}\right), \quad c=$ Ion concentration in the membrane $\left(\mathrm{mol} \mathrm{m}^{-3}\right), x=$ distance from the membrane $(\mathrm{m}), z=$ Valence of ion, $R=$ Gas constant $\left(\mathrm{J} \mathrm{mol}^{-1} \mathrm{~K}^{-1}\right), T=$ Absolute temperature $(\mathrm{K}), F=$ Faraday constant $\left(\mathrm{C} \mathrm{mol}^{-1}\right), K_{\mathrm{c}}=$ Hindrance factor for conversion, $\psi=$ Potential difference, and $V=$ Solvent velocity $\left(\mathrm{m} \mathrm{s}^{-1}\right)$.

The terms on the right hand side of the equation represent transport of solutes due to diffusion, electric gradient, and convention respectively. Thus the equation can predict solute rejection as a function of feed concentration, ion charge, convection across the membrane, and solute diffusion (Braghetta, 1995). It can be used to calculate the effective pore size (which does not necessarily mean that pores exist), and to determine the thickness and effective charge of the membrane (Bowen and Mukhtar, 1996).

The mass transport through a membrane could have as many as five steps such as (i) diffusion from the water phase to the surface of the membrane, (ii) selective portioning into the membrane phase, (iii) selective transport (diffusion) through the membrane, (iv) desorption from the permeate side of the membrane, and (iv) diffusion away from the membrane and into the bulk fluid of the extracting phase. Among these transfer operations, steps (i), (iii), and (v) may control the rate of mass transfer as the slowest step. Mass transport through NF can be described as diffusion-controlled processes. The different mechanisms and models used to describe the transport of solutes through a semi-permeable NF membrane are Donnan equilibrium, extended NernstPlanck, hindered transport, and irreversible non-equilibrium thermodynamics model. The use of the extended NernstPlanck model in conjunction with the Donnan equilibrium condition suggests the possibility of characterizing the effective membrane pore size and effective charge density to predict the separation of mixtures of electrolytes at the membrane/solution interface. Secondly, the non-equilibrium thermodynamic model provides a real description of ion transport through membranes even though the membrane is treated as a black box and the model gives little insight into the physico-chemical processes involved in solute and solvent transport across a membrane. Thus, the thermodynamic model can be accepted especially when the parameters used in the model are experimentally measured. The steric-hinderance pore (SHP) model is the modification of pore model where the gradient of mechanical pressure across a membrane is taken into account. Summary of the previous study on NF modelling is given in Table 3 (Lee and Lee, 2000; Yoon et al., 2002; Thanuttamavong et al., 2001; Ratanatamskul et al., 1998).

\section{Membrane fouling in the NF process}

Like any other membrane processes, NF is also susceptible to membrane fouling. Membrane fouling is one of the significant challenges in any membrane process and therefore understanding the fouling mechanism and identifying a suitable control option is one of the essential components of the membrane applications (Hong and Elimelech, 1997; Mulder, 1997; Lee et al., 2010; Phuntsho et al., 2011b). The solutions to fouling issues require a multipronged approach involving the membrane properties, operational conditions, feed characteristics, etc. (Chapman et al., 2002; Shon et al., 2005, 2009; Phuntsho et al., 2011a). The NF membrane fouling could be due to inorganic precipitation or scaling, colloidal fouling, organic adsorption and/or biofouling. While biofouling is important in long term, most likely, biofouling occurs only after organic or inorganic or colloidal fouling. Since interactions between solutes and the membranes are poorly understood, it is possible that effects like charge interactions, bridging, and hydrophobic interactions may play an important role in NF fouling. Normally, membranes with larger pores exhibit a greater flux decline as filtration proceeds because of internal clogging. However, flux decline is not necessarily due to fouling. Other phenomena such as concentration polarization or osmotic pressure or membrane compaction can appear as fouling during the NF process.

Reiss and Taylor (1994) compared three parameters, silt density index (SDI), modified fouling index (MFI), and the 
Table 3. Summary of the mathematical modeling work on Nanofiltration

\begin{tabular}{|c|c|c|}
\hline Modeling & Types & Remarks \\
\hline$\frac{\mathrm{d} m \cdot s}{\mathrm{~d} t}=-\frac{\mathrm{d}\left(\frac{J_{b}}{J_{w}}\right)}{\mathrm{d} t}$ & Cross flow & $\frac{\mathrm{d} m \cdot s}{\mathrm{~d} t}:$ the degree of concentration polarization \\
\hline$\frac{\mathrm{d} m \cdot c}{\mathrm{~d} t}=\frac{\mathrm{d}\left(\frac{J_{b}}{J_{t}}\right)}{\mathrm{d} t}$ & & $\begin{array}{l}\frac{\mathrm{d} m \cdot c}{\mathrm{~d} t}: \text { deposition probability and the bulk } \\
\text { crystallization rate }\end{array}$ \\
\hline$R=1-\frac{\left[1 /\left(t_{2}-t_{1}\right) \int_{t_{1}}^{t_{2}} L_{s}\left(C_{m}-C_{p}\right) \mathrm{d} t\right]}{\left[\left(f /\left(t_{2}-t_{1}\right) \int_{t_{1}}^{t_{2}} L_{v} \Delta P_{\mathrm{eff}} \mathrm{d} t\right]\right.}$ & Stirred cell & $\begin{array}{l}\text { The measured rejection matches the model } \\
\text { results quite well }\end{array}$ \\
\hline $\begin{array}{l}J_{s}=\omega \Delta \pi+(1-\sigma) C_{\mathrm{avg}} J_{v} \\
\text { (non-equilibrium thermodynamic equation) }\end{array}$ & Cross flow & $\begin{array}{l}\text { Solute flux is governed by convection for a } \\
\text { relatively large pore size membrane }\end{array}$ \\
\hline $\begin{array}{l}P=H_{D} S_{D} D_{S}\left(\frac{A_{k}}{\Delta x}\right) \\
H_{D}=1 \\
S_{D}=(1-\eta)^{2} \\
\eta=r_{s} / r_{p} \\
\text { (steric hindrance pore model) }\end{array}$ & Cross flow & $\begin{array}{l}\frac{A_{k}}{\Delta x} \text { : the ratio of porosity to membrane thick- } \\
\text { ness (value: } 4.4 \times 10^{3} \sim 7.8 \times 10^{4} \text { for } \mathrm{NF} \text { ) } \\
P: \text { solute permeability }\end{array}$ \\
\hline $\begin{array}{l}J_{i}=-u_{i} R T \frac{\mathrm{d} c_{i}}{\mathrm{~d} x}-Z_{i} c_{i} u_{i} F \frac{\mathrm{d} \Psi}{\mathrm{d} x}+c_{i} J_{v} \\
\text { (the extended Nernt-Planck equation) }\end{array}$ & Cross flow & $\begin{array}{l}\text { The difference in rejection between chloride } \\
\text { and nitrate was well explained by introduc- } \\
\text { ing a new parameter }\end{array}$ \\
\hline $\begin{array}{l}\sum_{i} Z_{i} C_{i}=0 \text { outside membrane } \\
\sum_{i} Z_{i} C_{i}+\varnothing X=0 \text { inside membrane } \\
\left(\frac{c_{i}}{C_{i}}\right)^{1 / Z_{i}}=\exp \left(\frac{-F \Delta \Psi D}{R T}\right) \\
\text { (Donnan equilibrium) }\end{array}$ & & \\
\hline
\end{tabular}

linear correlation of the mass transfer coefficient (MTC) to investigate the NF fouling. However, no correlation between these parameters was obtained indicating that the simple filtration laws might not be valid for NF process. DiGiano et al. (1994) found that the organic compounds with molecular weight higher than $30 \mathrm{kDa}$ was responsible for NF fouling. They further noticed the change in fouling mechanism after $20 \mathrm{~h}$ operation of NF, possibly due to the interactions of the hydrophobic and hydrophilic fractions of organics. Thorsen et al. (1999) recommended the use of highly hydrophilic NF membranes with pore size of $1-2 \mathrm{~nm}$ and low operating pressure to reduce fouling. They found that hydrophilic membranes were more fouling resistant irrespective of the pore size of the membranes. Membrane fouling would be very severe in positively charged membranes which can attract the negatively charged organics easily (Nystrom et al., 1995). Inorganic ions such as calcium, phosphorus, aluminium and iron etc. were found to enhance the membrane fouling during water treatment process (Baker et al., 1995). Hong and Elimelech (1997) showed that membrane fouling by NOM was increased in the presence of calcium ions, at lower $\mathrm{pH}$, and higher ionic strength. They further noted that permeation drag and electrostatic double layer repulsion controlled the membrane fouling. Chellam et al. (1997) found that colloidal materials could cause more fouling than organic in NF. The NF membrane fouling can occur due to the following rea- sons: (i) biological fouling which is the growth of biological species on the membrane surface, (ii) colloidal fouling which results in a loss of permeate flux through the membrane, (iii) organic fouling due to the deposition of organic substances, and (iv) scaling which is defined as the formation of mineral deposits precipitating from the feed stream to the membrane surface (Duranceau, 2001).

\subsection{Membrane fouling control}

Membrane fouling is normally controlled either by operating the system within the critical flux range or adding chemicals (especially to prevent inorganic scaling and fouling), and/or by pretreatment. Pretreatment is emerging as the most promising solution to control the fouling as it is simple and easy to implement. Gusses et al. (1997) and Glucina et al. (1997) found that conventionally used filter media was not sufficient to reduce the fouling of NF, and suggested a combination of coagulation, ozonation and biofiltration as a better alternative to reduce the NF fouling. Normally for coagulation as a pretreatment, iron or aluminium sulphate are commonly used. However, Nystrom et al. (1995) observed that when humic acid was filtered alone, it was retained to $100 \%$, but when filtered together with $\mathrm{FeCl}_{3}$, humic acid retention decreased. Thus, it requires to be wise on the use of physicochemical pretreatments before a NF module. Levenstein et 
al. (1996) found that addition of a polyelectrolyte enhanced the ion rejection in NF. Activated carbon adsorption is a very effective pretreatment process. Many researchers have used activated carbon adsorption as a pretreatment to membrane processes (Kim et al., 2001; Matsui et al., 2001a, b; Vigneswaran et al., 2003). Since the initial decrease in the permeate flux is mainly due to rapid, irreversible adsorption of organic substances on the membrane surface (Ben Aim et al., 1993), providing a pre-treatment such as adsorption or flocculation of organics before passing the feed solution through the membrane is very effective solution to the membrane fouling problem (Chapman et al., 2002). Backwashing, backflushing or chemical cleaning are some other options to reduce the NF fouling.

\subsection{Importance of pre-treatments prior to NF process}

Pretreatment of the feed to NF is one of the important considerations to protect the membrane and to improve the performance of NF. Protection refers usually to the prevention of fouling, but also includes the protection against mechanical and chemical damage. A high solids load can damage the membrane surface mechanically and restrict the flow in the filtration system. Meanwhile, oxidation agent, e.g. chlorine and ozone, are harmful to many membrane materials.

NF can be used in the tertiary wastewater especially to remove persisting organic pollutants. In order to improve the filtration flux of NF and extend the operation of NF without extensive organic fouling, effective pretreatment is necessary. In recent years, high rate flocculation and magnetic ion exchange resin have been tried to remove hydrophobic and hydrophilic organics respectively. This can greatly reduce the organic fouling on the NF membranes.

\section{Summary}

NF that is the widely used membrane process for water and wastewater treatment in addition to other applications such as desalination where its application is increasing plays an important role to partially replace $\mathrm{RO}$, which reduces energy and operational costs. The fundamentals of membrane process in general and the mechanisms of the NF process in particular with some of its basic models were discussed and the issues and challenges of the membrane fouling with $\mathrm{NF}$ applications have also been identified including the pretreatment options to mitigate the membrane fouling with the NF process. For the future, NF on behalf of RO will be preferentially considered if it meets water quality requirements.

Acknowledgements. This research was funded by Australian Research Council (ARC). This work was supported in part by the National Research Foundation of Korea (NRF) grand funded by the Korea government (MEST) (No. 2012047029, TOC).

Edited by: I. S. Kim

\section{References}

Baker, J., Stephenson, T., Dard, S., and Cote, P.: Characterisation of fouling of nanofiltration membranes used treat surface waters, Environ. Technol., 16, 977-985, 1995.

Ben Aim, R. and Semmens, M. J.: Membrane bioreactors for wastewater treatment and reuse: a success story, Proceedings and key-note speech of the IWA-Asian Environmental Technology Conference, Singapore, IWA, 2001.

Ben Aim, R., Liu, M. G., and Vigneswaran, S.: Recent development of membrane processes for water and wastewater treatment, Water Sci. Technol., 27, 141-149, 1993.

Bowen, W. R. and Mukhtar, H.: Characterisation and prediction of separation performance on nanofiltration membranes, J. Membrane Sci., 112, 263-274, 1996.

Bowen, W. R. and Welfoot, J. S.: Modelling the performance of membrane nanofiltration critical assessment and model development, Chem. Eng. Sci., 57, 1121-1137, 2002.

Bowen, W. R., Welfoot, J. S., and Williams, P. M.: Linearized transport model for nanofiltration: development and assessment, AIChE J., 48, 760-772, 2002.

Braghetta, A.: The influence of solution chemistry and operating conditions on nanofiltration of charged and uncharged organic macromolecules, Dissertation, University of North Carolina, USA, 1995.

Cadotte, J., Forester, R., Kim, M., Petersen, R., and Stocker, T.: Nanofiltration membranes broaden the use of membrane separation technology, Desalination, 70, 77-88, 1988.

Chapman, H., Vigneswaran, S., Ngo, H. H., Dyer, S., and Ben Aim, R.: Pre-flocculation of secondary treated wastewater in enhancing the performance of microfiltration, Desalination, 146, 367372, 2002.

Chellam, S., Jacangelo, J. G., Bonacquisti, T. P., and Schauer, B. A.: Effect of pretreatment for surface water nanofiltration, J. Am. Water Works Assoc., 89, 77-88, 1997.

Choi, J. H., Cockko, S., Fukushi, K., and Yamamoto, K.: A novel application of a submerged nanofiltration membrane bioreactor (NF MBR) for wastewater treatment, Desalination, 146, 5413 420, 2002.

DiGiano, F. A., Braghetta, A., Nilson, J., and Utne, B.: Fouling of nanofiltration membranes by natural organic matter, National Conference on Environmental Engineering, American Society of Civil Engineers, 1994.

Duranceau, S. J.: Membrane practices for water treatment, Denver, American Water Works Association, 2001.

Ernst, M., Sachse, A., Steinberg, C. E. W., and Jekel, M.: Characterization of the DOC in nanofiltration permeates of at tertiary effluent, Water Res., 34, 2879-2886, 2000.

Glucina, K., Laine, J. M., and Robert, C.: Intergrated, multiobjective membrane systems for surface water treatment, Proceedings AWWA Membrane Technology Conference, New Orleans, USA, 1997.

Gozalvez, J. M., Lora, J., Mendoza, J. A., and Sancho, M.: Modelling of a low-pressure reverse osmosis system with concentrate recirculation to obtain high recovery levels, Desalination, 144, 341-345, 2002.

Gusses, A. M., Allgeier, S. C., Speth, T. F., and Summers, R. S.: Evaluation of surface water pretreatment processes using rapid bench-scale membrane test, Proceedings AWWA Membrane 
Technology Conference, New Orleans, USA, 1997.

Hong, S. and Elimelech, M.: Chemical and physical aspects of natural organic matter (NOM) fouling of nanofiltration membranes, J. Membr. Sci., 132, 159-181, 1997.

Kim, H. S., Katayama, H., Takizawa, S., and Ohgaki, S.: Removal of coliphage $\mathrm{Qb}$ and organic matter from synthetic secondary effluent by powdered activated carbon-microfiltration (PACMF) process, Proceedings of IWA Specialized Conference on Membrane Technology, Israel, 211-219, 2001.

Lee, E., Shon, H. K., and Cho, J.: Biofouling characteristics using flow field-flow fractionation: Effect of bacteria and membrane properties, Bioresource Technol., 101, 1487-1493, 2010.

Lee, S. and Lee, C.-H.: Effect of operating conditions on $\mathrm{CaSO}_{4}$ scale formation mechanism in nanofiltration for water softening, Water Res., 34, 3854-3866, 2000.

Lee, S., Shim, Y., Kim, I. S., Sohn, J., Yim, S. K., and Cho, J.: Determination of mass transport characteristics for natural organic matter (NOM) in ultrafiltration (UF) and nanofiltration (NF) membranes, Water Sci. Technol., 2, 151-160, 2002.

Levenstein, R., Hasson, D., and Semiat, R.: Utilization of the Donnan effect for improving electrolyte separation with nanofiltration membranes, J. Membr. Sci., 116, 77-92, 1996.

Macoun, R. G.: The mechanisms of ionic rejection in nanofiltration, Chemical Engineering, Ph.D. thesis, University of New South Wales, Sydney, Australia, 1998.

Matsui, Y., Colas, F., and Yuasa, A.: Removal of a synthetic organic chemical by PAC-UF systems - II: Model application, Water Res., 35, 464-470, 2001a.

Matsui, Y., Yuasa, A., and Ariga, K.: Removal of a synthetic organic chemical by PAC-UF systems - I: theory and modeling, Water Res., 35, 455-463, 2001b.

Mulder, M.: Basic principles in membrane technology, Kluwer Academic Publishers, 1997.

Nystrom, M., Kaipia, L., and Luques, S.: Fouling and retention of nanofiltration membranes, J. Membr. Sci., 98, 249-262, 1995.

Phuntsho, S., Listowski, A., Shon, H. K., Le-Clech, P., and Vigneswaran, S.: Membrane autopsy of a 10 year old hollow fibre membrane from Sydney Olympic Park water reclamation plant, Desalination, 271, 241-247, 2011a.

Phuntsho, S., Shon, H. K., Vigneswaran, S., and Cho, J.: Assessing membrane fouling potential of humic acid using flow field-flow fractionation, J. Membr. Sci., 373, 64-73, 2011 b.

Ratanatamskul, C., Urase, T., and Yamamoto, K.: Description of behaviour in rejection of pollutants in ultra low pressure nanofiltration, Water Sci. Technol., 38, 453-462, 1998.

Reiss, C. R. and Taylor, J. S.: Prediction of nanofilter productivity decline using fouling indices, Proceedings AWWA Membrane Technology Conference, Nevada, USA, 1994.

Rohe, D. L., Blanton, T. C., and Marinas, B. J.: Drinking water treatment by nanofiltration, National conference on Environmental Engineering, 1990.

Seidel, A. and Elimelech, M.: Coupling between chemical and physical interactions in natural organic matter (NOM) fouling of nanofiltration membranes: implications for fouling control, J. Membr. Sci., 203, 245-255, 2002.

Seo, G. T., Suzuki, Y., and Ohgaki, S.: Bilogical powdered activated carbon (BPAC) microfiltration for wastewater reclamation and reuse, Desalination, 106, 39-45, 1996.
Seo, G. T., Ohgaki, S., and Suzuki, Y.: Sorption characteristics of bilogical powdered activated carbon in BPAC-MF (biological activated carbon-microfiltration) system for refractory organic removal, Water Sci. Technol., 35, 163-170, 1997.

Shannon, M. A., Bohn, P. W., Elimelech, M., Georgiadis, J. G., Marinas, B. J., and Mayes, A. M.: Science and technology for water purification in the coming decades, Nature, 452, 301-310, 2008.

Shon, H. K., Vigneswaran, S., Aim, R. B., Ngo, H. H., Kim, I. S., and Cho, J.: Influence of Flocculation and Adsorption as Pretreatment on the Fouling of Ultrafiltration and Nanofiltration Membranes: Application with Biologically Treated Sewage Effluent, Environ. Sci. Technol., 39, 3864-3871, 2005.

Shon, H. K., Vigneswaran, S., Zareie, M. H., Aim, R. B., Lee, E., Lee, J., Cho, J., and Kim, I. S.: Physico-chemical pretreatment to seawater reverse osmosis (SWRO): organic characterization and membrane autopsy, Desalination, 236, 282-290, 2009.

Simpson, A. E., Kerr, C. A., and Buckley, C. A.: The effect of pH on the nanofiltration of the carbonate system in solution, Desalination, 64, 305-319, 1987.

Snoeyink, V. L., Campos, C., and Marinas, B. J.: Design and performance of powdered activated carbon/ultrafiltration systems, Water Sci. Technol., 42, 1-10, 2000.

Thanuttamavong, M., Oh, J. I., Yamamoto, K., and Urase, T.: Comparison between rejection characteristics of natural organic matter and inorganic salts in ultra low pressure nanofiltration for drinking water production, Water Sci. Technol., 1, 77-90, 2001.

Thanuttamavong, M., Yamamoto, K., Oh, J. I., Choo, K. H., and Choi, S. J.: Rejection characteristics of organic and inorganic pollutants by ultra low-pressure nanofiltration of surface water for drinking water treatment, Desalination, 145, 257-264, 2002.

Thorsen, T.: Membrane filtration of humic substances - State of the art, Water Sci. Technol., 40, 105-112, 1999.

Trebouet, D., Schlumpf, J. P., Jaouen, P., and Quemeneur, F.: Stabilized landfill leachate treatment by combined physicochemicalnanofiltration processes, Water Res., 35, 2935-2942, 252001.

Tsuru, T., Izumi, S., Yoshioka, T., and Asaeda, M.: Temperature effect on transport performance by inorganic nanofiltration membranes, AlChE J., 46, 565-574, 2000.

Van der Bruggen, B., Braeken, L., and Vandecasteele, C.: Evaluation of parameters describing flux decline in nanofiltration of aqueous solutions containing organic compounds, Desalination, 147, 281-288, 2002.

Vigneswaran, S., Vigneswaran, B., and Ben Aim, R.: Application of microfiltration for water and wastewater treatment, Environmental Sanitation Reviews, 31 June, 1991.

Vigneswaran, S., Chaudhary, D. S., Ngo, H. H., Shim, W. G., and Moon, H.: Application of a PAC-Membrane Hybrid System for Removal of Organics from Secondary Sewage Effluent: Experiments and Modelling, Separ. Sci. Technol., 38, 2183-2199, 2003.

Visvanathan, C., Ben Aim, R., and Parameshwaran, K.: Membrane separation bioreactors for wastewater treatment. Critical reviews, Environ. Sci. Technol., 30, 1-48, 2000.

$\mathrm{Xu}, \mathrm{Y}$. and Lebrun, R. E.: Comparison of nanofiltration properties of two membranes using electrolyte and non-electrolyte solutes, Desalination, 122, 95-106, 1999.

Yoon, Y., Amy, G., Cho, J., Her, N., and Pellegrino, J.: Transport of perchlorate $\left(\mathrm{ClO}_{4}\right)$ through $\mathrm{NF}$ and Membranes, Desalination, 147, 11-17, 2002. 